\title{
COMPETITIVENESS - HIGHER EDUCATION
}

\author{
Labas Istvan \\ University of Debrecen, Hungary \\ email: labas.istvan@econ.unideb.hu \\ Darabos Eva \\ University of Debrecen, Hungary \\ Nagy Tunde Orsolya
}

University of Debrecen, Hungary

(Received October 2015; accepted February 2016)

\begin{abstract}
Involvement of European Union plays an important role in the areas of education and training equally. The member states are responsible for organizing and operating their education and training systems themselves. And, EU policy is aimed at supporting the efforts of member states and trying to find solutions for the common challenges which appear. In order to make our future sustainable maximally; the key to it lies in education. The highly qualified workforce is the key to development, advancement and innovation of the world. Nowadays, the competitiveness of higher education institutions has become more and more appreciated in the national economy. In recent years, the frameworks of operation of higher education systems have gone through a total transformation. The number of applying students is continuously decreasing in some European countries therefore only those institutions can "survive" this shortfall, which are able to minimize the loss of the number of students. In this process, the factors forming the competitiveness of these budgetary institutions play an important role from the point of view of survival. The more competitive a higher education institution is, the greater the chance is that the students would like to continue their studies there and thus this institution will have a greater chance for the survival in the future, compared to ones lagging behind in the competition. Aim of our treatise prepared is to present the current situation and main data of the EU higher education and we examine the performance of higher education: to what extent it fulfils the strategy for smart, sustainable and inclusive growth which is worded in the framework of Europe 2020 programme. The treatise is based on analysis of statistical data.
\end{abstract}

Keywords: competitiveness, higher education institutions, Europe 2020 programme

\section{Introduction}

Nowadays, the social researchers have to face a very large challenge and this is nothing more than the globalisation. This is a phenomenon unfolding at an amazing speed - a multi-dimensional and multi-actor process affecting every element of the social formation (Palankai, 2014); we need a total paradigm shift to understand it. 
Its main characteristics include the spreading of manifold forms of the competition and cooperation, the relationship system of the technology, economy and social subsystems being much more complicated than the one known previously and the mutually existing dependence.

The rapid and radical changes directly affect the higher education as well. Involvement of the European Union plays a more and more important role in the areas of education and training equally. In accordance with the principle of subsidiarity, the decision about the higher education policies is made at level of each EU member state in the European Union. Therefore, role of the EU is confined to the support and, in part, the coordinating activity. For this reason, it can act only in accordance with the ordinary legislative procedure and by incentives thus, unfortunately, the laws and regulations of the member states cannot be harmonized.

As I already mentioned, the member states are themselves responsible for organizing their education and training systems as well as for operating them and the Union policy is aimed at supporting the efforts of member states.

In order to make our future maximally sustainable - the key to it lies in education. The highly qualified workforce is the key to development, advancement and innovation of the world (Krenner, 2014).

In their published treatises, many people have already dealt with it and have proved close correspondence regarding the fact that the higher the quality of education is, the higher the intellectual development tendency. In order to reach development and quality improvement in the area of education, modifying the structure change and establishing a more serious competition will be required in the future.

However, transformation of the higher education can be determined as a very timeconsuming process. If we want to build such a long-term sustainable higher education system regarding the countries "lagging behind" which is competitive by the European standards, we have to take sufficient time so that the institutions as well as the society themselves shall adopt the modified conditions (I1).

\section{Future of education}

Successful operation of the higher education is of key importance for the purposes of long-term growth of the economy (Aghion et al., 2008) and ,its internationally recognized performance can improve the overall picture of economy and society a lot" (Torok, 2009). In short, the highly qualified workforce is the key to development, advancement and innovation of the world (Krenner-Horneffer, 2014).

The higher the quality of education is, the higher the intellectual development tendency. Thus, it is important that the higher education institutions shall directly as well as indirectly play decisive roles both in our personal and social 
development. Education has a fundamental task with respect to the fact that Europe should possess a highly qualified human capital and educated persons because this is the only way for Europe to be able to establish jobs with appropriate quality, to produce economic growth and to ensure welfare for their citizens.

$40 \%$ of the European juveniles shall have higher education qualifications by 2020 ; this is fixed as a strategic goal by the Europe 2020 strategy. With regard to the achievement of lifelong learning and mobility, second paragraph of Article 165 of TFEU (Treaty on the Functioning of the European Union) specifically lists the goals of EU actions which are manifested in the following in case of the area of higher education:

- developing the European dimension in education;

- inciting the mobility;

- contributing to the cooperation between the educational institutions;

- developing the change of information and experiences regarding the question about education systems of the member states equally;

- inciting the development of distance-learning.

The Europe 2020 strategy focusing on the intelligent, sustainable and inclusive growth is willing to achieve its goals by more effective investments in the research and innovation (I2).

Basic goal of the Europe 2020 strategy is that at least $40 \%$ of 30-34-year-old persons shall have higher education qualifications by 2020. The strategy framework "Education and Training 2020", which is based on the work program "Education and Training 2010" and was accepted in March of 2009 by the European Council, has already mentioned this kind of objective and has set common strategic goals for the member states.

According to the statistical data of Statdat, the ratio of graduated people is the highest in Lithuania where half of the age-group in question i.e. 53.3\% have higher education qualifications. Luxembourg is the second with 52.7\% and Cyprus is the third where $52.2 \%$ of the 30-34-year-old persons are graduates. In 2013, 6 countries reached the union expectation of $40 \%$. The file-closer is Turkey where $21 \%$ of the people are graduate which is overtaken with $23.9 \%$ by Italy. $22.4 \%$ of the people between 30 and 34 years finished in higher educational institutions in Romania. (Figure 1)

The different levels of the member states' efforts are reflected by the fact that the national objectives are between the Italian 26\% and the Irish 60\%. In 2013, 10 member states - Lithuania, Luxembourg, Cyprus, Sweden, Estonia, Finland, Denmark, the Netherlands, Slovenia and Austria - already reached their objectives. Portugal, Croatia, Slovakia and Malta are the farthest from achievement. Some countries have set quite high goals conversely the Italian plans of $26 \%$ - for example $40 \%$ in case of Slovakia and Portugal, 60\% in case of Ireland and 66\% in 
case of Luxembourg. According to the forecasts of 2020, most countries will probably reach their objectives - supposedly excluding Malta, Portugal and Slovakia.

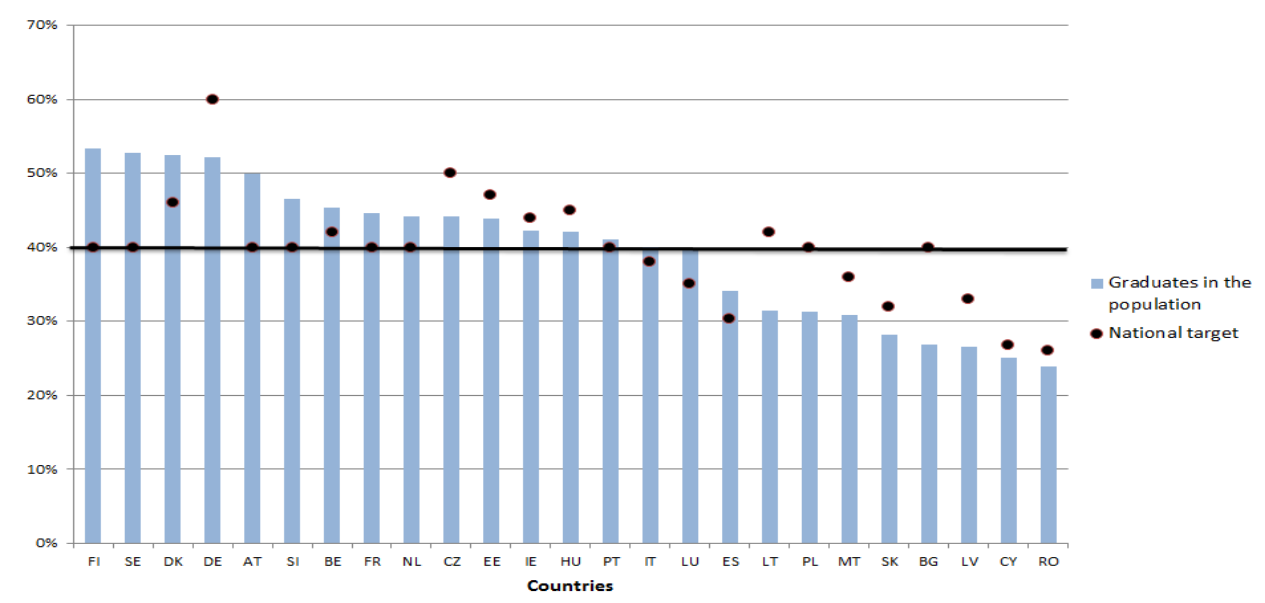

Figure 1: Proportion of graduates in the age of 30-34 (2013)

Source: Eurostat, 2015

Based on the above-mentioned things, therefore it becomes increasingly important in the area of education and training that a kind of closer cooperation should be created between the institutions and workplaces of each country. This will ensure the training opportunity for a particular labor force.

Actually the present goal for the member states is that they all can establish the best higher education system of a given country or region and the focus should be on the performance, high quality, competitive knowledge as well as the common success of teachers and students.

The following points are the main areas to be changed currently in Hungary:

1. increasing the requirements for the students,

2. rationalizing the institution network,

3. funding based on first-cost recognized,

4. renewing the teachers' training,

5. increasing the number of researchers.

\section{Development in the number of students in higher education}

By the $21^{\text {st }}$ Century, the European higher education lost its attractiveness and leading position which had been typical before the Second World War. In the first half of the $19^{\text {th }}$ Century, attractiveness of the European leading universities was outstandingly strong, a large number of students wishing to learn abroad had 
crowded into our continent from numerous countries of the world; it meant that the European higher education had been able to attract the prospective talents from countries outside Europe.

After the war, the situation totally changed: unfortunately, the European higher education and a large proportion of the European universities lost their hard-won competitiveness. The war caused a massive destruction in the infrastructure; scientists escaped en masse from Europe to America. The USA came out victorious from the war not just militarily but in the aspect of economy and science as well. The US universities strengthened and, due to it, their attractiveness and competitiveness grew. In this way, they were able to attract the prominently talented students and young scientists to the USA from the Third World and indeed Europe. As a result of all these, the US universities reached the biggest share on the market of students paying tuition; due to this, as it is also shown by the statistics of Nobel laureates, they took the leader role in the area of innovation as well.

We have internationally examined the development in number of students between 2009 and 2012 which can be seen in Table 1 in detail.

Table 1. Number of students in the higher education between 2009-2012

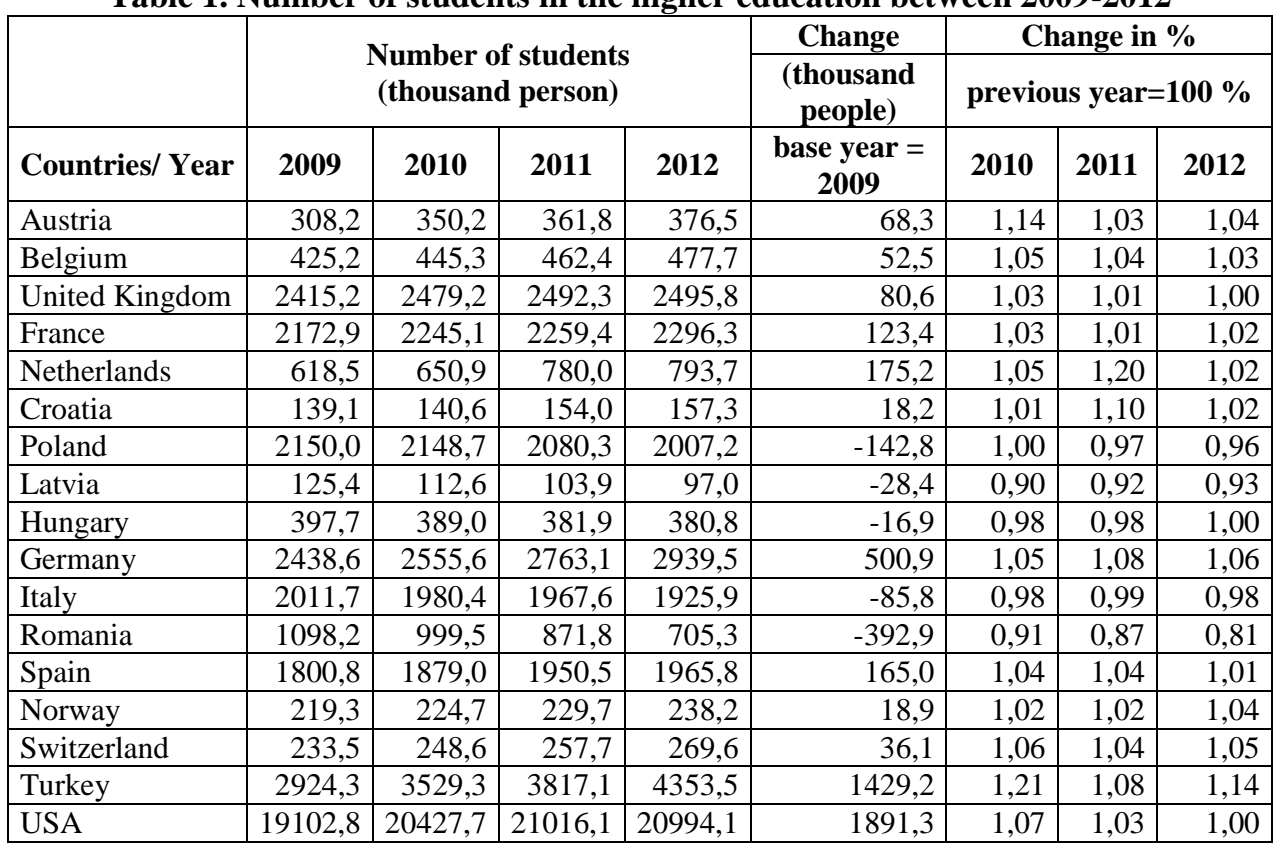

Source: Statadat, 2014

DE GRUYTER OPEN 
It can be experienced that the number of students has increased in countries which have the largest number of students (the United Kingdom, France, Germany, Spain, Turkey and the United States) and in some countries having lower number of students such as Austria, Belgium, the Netherlands, Croatia, Norway or Switzerland. The growth in number of students can be from a few thousand people to almost 1.9 million persons. At the same time, compared to the previous year, regression can be observed in most countries in 2012 with regard to the growth.

Only Austria stands out among the surrounding countries: here, the extent of growth in number of students was $13.6 \%$ from 2009 to 2010 .Then, the trend of growth has continued. It was almost $3-4 \%$ from year to year which means an increase of 68 thousand persons during 4 years. In one respect, its cause may be the free education provided in Austria; on the other hand, the participants can get into a training more easily. The students have to pay only EUR 17 for a semester as a socalled study charge (Studeingebuhr) which is not spent on financing the education but the students contribute to the operation of student council in this way. However, this non-payment persists for a definite period. Insofar as a student does not complete a major within 9 semesters during the basic education then he/she will have to pay for the education. The grace period lasts seven semesters in case of master degrees.

There was clear reduction in the number of students in some Eastern European countries (Poland, Latvia, Lithuania, Hungary, Romania, Slovakia and Slovenia) and in Italy. The largest reduction in the number of students was in Latvia, Hungary, Italy and Romania and, of course, there are significant differences in the numbers here.

\section{Competitiveness of nations}

In addition to the general competitiveness, it is also important to mention the competitiveness of nations which may be the most expounded issue albeit, in this case either, we cannot find a unified definition accepted by everyone. This problem has preoccupied the economists since Adam Smith, the father of modern economics: what do the richness and welfare of nations depend on?

According to the idea of the most general approach, the competitiveness is the ability of national economies to produce certain goods under such conditions which are more favourable than others'. It should be defined what purposes we would like to achieve through the competitiveness and what specific abilities are required for achieving them. Throughout history, the sphere of factors determining the competitiveness of nations significantly changed but striving for the competitiveness appears in every era. In later ages, the influencing factors include the specialization, division of labour, investment in productive capital and the infrastructure. 
More recently, investment in such factors has been placed on the agenda such as education and training, technological advancement, macroeconomic stability, good government, rule of law, transparency, and well-functioning institutional system.

The model evolved by the World Economic Forum defines 12 essential factors which can be regarded as pillars of competitiveness and, at the same time, these ones do not exclude each other mutually. The pillars can be classified into three groups:

- basic requirements,

- efficiency enhancers,

- innovation and sophistication factors.

Creators of the model decided what factors are included by the single pillars. These are the following:

Basic requirements: this category includes those factors which are just minimally required for remaining in the competition at all: institutional system, infrastructure, macroeconomic stability, health service and primary education.

Efficiency enhancers: these ones can be helpful in withstanding in a way of a certain kind; higher education and training, marketability of products, labor force efficiency, complexity of financial systems, technological susceptibility.

Innovation and sophistication factors: those factors can be listed here which can already give hope to reach an outstanding competition performance; complexity and sophistication of business life, innovation.

\section{Competitiveness of higher education}

We meet the competition itself at every moment of our life. The definitions are differently determined in dictionaries and specialist books but there is an essential common element of these: the emergence, the advancement compared to the other competitors.

In a more complex wording, it means the existence of such excellent abilities and possibilities based on which we can take part in the competition, in the hope of victory and success. It can be sensed only from this commonplace that, in one respect, we are talking about rivalry; on the other hand, those abilities based on which we can build up our competition strategy shall be found for a successful withstanding in the competition. Furthermore, we shall explore those environmental possibilities and areas on which we may have a chance for success.

Some of the great names of the profession have circumscribed this concept as follows:

Attila Chikan has worded the following: the concepts of competition and the market can be imagined just simultaneously and the competition means an activity between two or more operators which focuses on gaining advantage and takes place under particular rules. 
According to Porter, a kind of mutual interdependence can be experienced between the participants in the economic market, by which the economic operators affect the operation of each other as well. However, it is important to ascertain and highlight the fact that it is difficult to present and describe the performance of higher education by means of the economic definitions which are usually used in the other sectors.

We constantly use this concept on a daily basis but, unfortunately, we cannot determine the competitiveness of higher education exactly; this is a dissimilar and specific market segment.

We would like to summarize the causes briefly in the following: the output cannot be collated in this segment and, in the absence of conditions of the Pareto optimality, the scales of success cannot be determined either.

Today, unfortunately, the emphasis is not on knowledge in most of the EU member states but on the effort to graduate as soon as possible and, in the long-term, this is not competitive compared to the "developed" Northern knowledge and approach. Our present education system does not prepare the students for the thinking but it fully operates in an exam-oriented manner, which makes the future work activities of students impossible.

After entering the "market", the graduates are not able to cope with their workplace duties since, within the framework of higher education; they did not encounter each kind of exam examples which is a phenomenon that may occur in life. They are not "capable" of thinking, that's why this situation will remain unsolved for a long time.

Nowadays, some countries would have to work up/transform the training level properly because the trainings are still merged in many cases, including Hungary, while the $\mathrm{BA} / \mathrm{Ma} / \mathrm{PhD}$ trainings are separated in the case of Western member states.

In addition, it would be required to incite the team of teachers duly since, without doing this, the proper evolving of competitiveness becomes almost impossible.

In order for the persons having higher education qualifications in our country to get not only diploma but also knowledge, a structure change is required in the education system; an establishment of competition should be incited between the higher education institutions and the to-be workforce and, in addition, the "diploma manufacturing" shall be ceased. Its first step is to change grade in the higher education.

\section{Issues determining the competitiveness of higher education institutions}

In his essay entitled 'Higher educational competitiveness and strategy', Karoly Barakonyi draws attention to the profoundness of clarifying the basic concepts which is necessary for the professional, political and social discourse. He places the 
topic in an international context (EU, OECD) but he gets through to the strategy creation of the higher educational institutions and the most important factors influencing the competitiveness of higher educational institutions (Barakonyi, 2014).

In addition to him, other Hungarian authors -Adam Torok and Magda Andrea Nagy - also deal with the competitiveness of higher education; their treaties already connect the economical approach with the expressly higher educational relations and institutional ranking lists. This reason is that the ranking can also be regarded as a competitiveness analysis of the same kind.

According to their notion, the higher educational competition is a multi-actor game of a certain kind and, by means of this aspect; they bring us closer to the recognition as well as understanding of career and limits of the institutional ranking lists. In their works/writings, they compared the results of the leading international ranking lists to each other and then they searched for the answer to a basic question on empirical approach:

- What connection can be proved between the higher educational ranking list and the competitiveness ranking list? (Essay of Attila Chikan). Attila points at how we should avoid the simplified interpretation of an undoubtedly existing coherence, the overestimation of the partial indicators. In his opinion, the higher education is an extremely complex social sub-system; it is worth examining its performance and effect on an approach correspondingly.

Gyorgy Fabri already deals with the ranking lists explicitly; he goes around the relating main objections, the theoretical and methodological disputes. He primarily deals with the possible effects with regard to the well-known and high-impact international ranking lists, in terms of what role those ones play in retaining or overshadowing the academic values as well as how these ones affect the different actors of the higher educational arena. One key issue to make a ranking list is the selection of the proper indicators, weighing of the indicators and the quality of data utilized.

Andres Telcs Andras and Tibor Zsolt Kosztyan chose such a solution which parries the traps in the indicators just by means of its simplicity. They examined the order of preference as well as the factors affecting the selection of institution itself based on student applications.

Finally, it is important to emphasize that both the supply side and the demand side shall be taken into consideration during the competitiveness analysis (Torok, 2006).

Nowadays, more and more ranking lists are published which take the viewpoints of the demand side as well. During the evaluation of higher educational institutions, we shall consider the applicants' decision-making criteria, preference as well as the 
quality features of the students anyway (Nikolaidis - Dimitriadis, 2014).The following diagram serves for proving the above-mentioned:

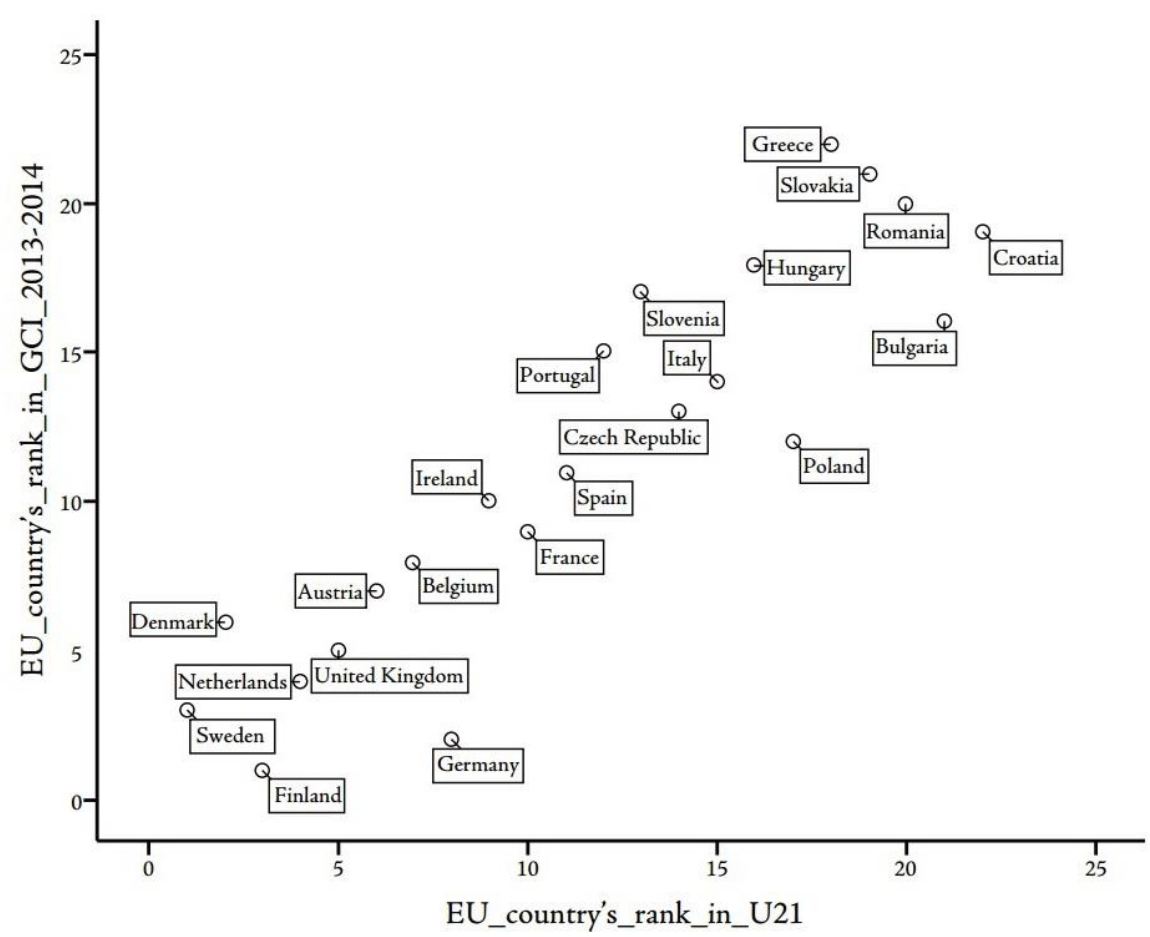

Figure 1. Higher education ranking list 2014

Source: Adam Torok and Magda Andrea Nagy: Forms, operators and stakeholders on the higher education market based on treatise

By summarizing the above, it can be determined which partial basic factors are required to be changed in order to step forward in this area. However, the following have to be handled as stressed questions; it is important that these ones will gain ground when the prospective strategic plans are shaped up:

- What does competitiveness mean in higher education?

- Who do we compete with?

- What position do we start from and where would we like to get to?

- In what segment of knowledge market would we like to be successful?

- What abilities are required for success?

- How can these ones be developed, acquired? (I2)

It was already partly explained above why it is difficult to determine the definition of the competitiveness of higher education. These questions shed light upon the 
fact that this is a more complex problem than we might think at first. Namely, it is impossible to give an appropriate question until clear answers can be provided for the asked questions. In order to apply this concept properly later separated from a general conceptual definition, it is required to take individual characteristics into consideration.

In our opinion, the competitiveness is influenced by the following main basic factors:

1. Quality of the input factors,

2. Financing,

3. Utilization of the financial resources,

4. Appropriate level and quality criteria of the education,

5. Internationality,

6. Technological development,

7. International recognition.

\section{Opportunity to break out; does it exist?}

The competitiveness of some European universities, colleges is not the same as the competitiveness of the given national higher education: this is about other racecourse, other criteria and other factors (I3).

As the national competitiveness cannot exist without excellent enterprises, an internationally competitive higher education system cannot be imagined without such universities and colleges being open outwards which are competitive on the international stage as well (I4).

In order for the institutions of the member states to become competitive and internationally accepted, the decisive pillars should be thought over profoundly and should be formed accordingly. Key to the modern competitive higher education lies in it.

So, the structure change is indispensably required in the higher education institutions of some countries.

The present problem shall be handled at system level and "fire-fighting" or "patchwork" shall not be performed.

For this reason, the system-level problem management and the strategic planning of the future of higher education have become indispensable and necessary.

How does the controlling support the competitiveness through DEA system?

Competiveness is one of the most commonly used terms of nowadays; it increasingly becomes a tool for the overall qualification and performance measurement of the economies (Torok, 2003).

One of the most overall analyses is performed by the World Economic Forum annually and its outcome is published in a publication entitled Global 
Competitiveness Report. In this list, Hungary is reckoned as the $60^{\text {th }}$ most competitive economy of the world (I5).

Throughout the world, it is a proven fact that the capital as well as work invested in education, especially in higher education are best utilized in the area of human resources thus directly in the economy.

Nowadays, the statement increasingly prevails; in one respect, obtaining a university or college diploma becomes an important purpose for more and more juveniles, on the other hand, the diploma has become fully accepted in the sphere of corporations as one of the possible indices of the relevant expertise on the labor market. (Majo, 2000)

According to the interpretation of Barakonyi, the competitiveness of higher education is not an important question by itself but it is a decisive factor for improving the competitiveness of the nation. "There is no competitive nation without competitive higher education.” (Barakonyi, 2014)

As set out above, in my opinion, competitiveness in higher education can be increased through the controlling system in such a way that the future survival can be advanced by enhancing the effectiveness of decisions made in the education, since the manner we react on the pressure given by a specific environment is greatly determined by the headstones of operation of the available controlling system and the benchmarking -DEA which evaluates the efficiency of the decision made (Fenyves - Tarnoczi, 2014).

\section{Benefits of using DEA methodology}

Charnes describes DEA as a new way of organizing and analysing data, which can result in new managerial and theoretical insights. They highlight the following properties of DEA which make it an attractive approach to data analysis:

- Focus on individual observations in contrast to population averages.

- Produce a single aggregate measure for each DMU in terms of its utilization of input factors to produce desired outputs.

- Can simultaneously utilize multiple outputs and multiple inputs with each heingstated in different units of measurement.

- Can adjust for exogenous variables.

- Can incorporate categorical variables.

- Are value free and do not require specification or knowledge of a priori weighing or prices for the inputs and outputs.

- Place no restriction on the functional form of the production relationship.

- Can accommodate judgment when desired.

- Produce specific estimates for desired changes in inputs and/or outputs for projecting DMUs below the efficient frontier onto the efficient frontier.

- Is Pareto optimal? 
- Focus on revealed best-practice frontiers rather than on central-tendency properties of frontiers.

- Satisfy strict equity criteria in the relative evaluation of each DMU. (Charnes et al, 1994)

\section{Areas of applying DEA}

Since the first application of DEA for measuring the efficiency of schools the technique has been applied in over 50 industries to date (Charnes, 1978). Some of the application areas include the financial industry, the airline industry, the healthcare industry, the brewing industry, transportation, athletics, the farming industry, the computer industry, the mining industry, the software industry, and the U.S. army and so on. (Paul, 1997)

In my opinion, DEA analysis method could be the most suitable for determining the relative effectiveness for the non-profit oriented budgetary policy.

\section{Conclusion}

In our higher education system operating presently, it would be necessary to construe the competitiveness of higher education as a concept more accurately, and, in parallel, to determine and position the factors influencing the competitiveness, to set targets and to elaborate a higher educational strategy which can result in achieving the targets set.

It can be stated that the competitiveness of higher education is not a stand-alone thing. This is a prominent and decisive factor of the competitiveness of a nation. Unfortunately, it must be said that there is no competitive nation without competitive higher education. For this purpose, firstly, it is necessary to recognize the relations of the knowledge market, to clarify the basic concepts of the higher educational competitiveness and to define the pillars determining the competitiveness.

Examination of the different nations' higher educational system competitiveness (e.g. SWOT analysis, DEA methodology) can be performed only in light of recognizing the above mentioned things and, based on the statements of these examinations; the development goals of higher educational system can be set.

Unfortunately, many countries face the same problem as Hungary and it can be determined based on the research of Eva Berde that we may expect a high rate of decrease in the number of higher education-aged juveniles in subsequent years but it simultaneously conceals a so-called historic opportunity since the proportion of graduates can be increased without enlarging the existing capacity of higher education, only the present number of students should be retained. This concerns not only Hungary but, unfortunately, various other European higher education institutions as well. 
Consequently, the advantage arising from the demographic decline in headcount should not be a long-term goal in this way.

It would be required for the countries having a reduction in the number of students to be able to step out of the negative trend of the present number of students; and this could take place during a strategy establishment covering the given country. In order for more people to apply to higher education institutions for further study, it would be important to popularize and develop the learning opportunities as well as to greatly strengthen the moral and material recognition of both the learning and education in those countries where big regression can be experienced.

Insofar as breakout points succeeded to be carried out then the development of regions, countries as well as the enlargement of their competitiveness would be feasible. The professional knowledge could be kept at home and would contribute to the GDP of the home country and its growth there. It can be seen that the key to the economic development is the appropriate education as well.

\section{References}

1. Aghion P. (2008): Higher aspirations: an agenda for reforming European universities. Bruegel Blueprint 5, 59.

2. Barakonyi K. (2014): Felsőoktatasi versenykepesseg es strategia. Educatio, 2014/4. 555-566. oldal.

3. Berde E. (2013): A felsöoktatas lehetseges letszampalyai Magyarorszagon, Statisztikai Szemle, 91. evfolyam 1. szam.

4. Charnes,A. Cooper, W.W.. Rhodes. E. "'Measuring the Epciency of Decision Making Limits". European Journal of Operational Research, Vol. 2. No. 6, pp. 429444, 1978.

5. Charnes,A., Cooper, W. W.. and Seiford.L.M., "Basic DE4 ModeLr", in Data Envelopment Analysis: Theory, Methodology and Application, Charnes et al. Editors, Kluwer Academic Publishers, 1994.

6. Chikan A. (2005): Vallalatgazdasagtan, Aula Kiado, Budapest

7. Fenyves, V. and Tarnoczi, T. (2014) ''Teljesítmenyertekeles a DEA felhasznalasaval", Controller Info, Vol. 2, No. 1, pp.54.

8. Krenner D. - Horneffer B. (2014): Erhebung zu Karriervwerlaufen und internationaler Mobilitat von Hochqualifizierten. Witschaft und Statistik. 52-61 oldal. In: Statisztikai Szemle, 92. evfolyam 5. szam.

9. Majo Z. (2000): A felsőoktatas es a munkaerőpiac kapcsolata. In: Farkas B. Lengyel I. (szerk): Versenykepesseg - regionalis versenykepesseg. SZTE Gazdasagtudomanyi Kar Kozlemenyei. JATEPress, szeged, 169-186.oldal.

10. Nikolaidis, Y. - Dimittriadis, S. G. (2014): On the student evaluation of university courses and faculty members' teaching performance. European Journal of Operational Research, 238, 1, 199-207. 
11. Palankai T. (2014): Előszo. Jody Jensen: Globalizacio es uj kormanyzas. MTA Tarsadalomtudomanyi Kutatokozpont Politikatudomanyi Intezet. Mundus Novas Konyvek, Budapest

12. Porter M. (1990): The Competitive Advantage of Nations, The Free Press, New York

13. Torok A. (2003): Mit merunk mivel? A versenykepesseg ertelmezeseről es meresi problemairol. EU csatlakozas es versenykepesseg. Europa Tukor Mühelytanulmanyok 93. Budapest, 73-106. oldal.

14. Torok A. (2006): Az europai felsőoktatas versenykepessege es a lisszaboni celkitüzesek. Mennyire hihetunk a nemzetkozi egyetemi rangsoroknak? Kozgazdasagi Szemle, 53., 4., 310-329.

15. Torok A. (2009): Verseny a felsőoktatasban - így mertek ti. In: Murakozy Laszlo (szerk.) A jelen a jovő multja. Jaratlan utak - jart uttalansagok. Budapest, Akademiai Kiado, 2009., 241-294.

I1: http://ec.europa.eu/education/policy/higher-education/index_hu.htm

I2: http://mandiner.hu/cikk/20150730_palkovics_fenntarthato_felsooktatas_kell

I3: http://mandiner.hu/cikk/20150612_palkovics_a_regio_legjobb_felsooktatasa_ lesz_a_magyar_tiz_ev_mulva

I4: http://epa.oszk.hu/01500/01551/00070/pdf/EPA01551_educatio_2014_04_555566.pdf

I5: http://reports.weforum.org/global-competitiveness-report-2014-2015/rankings/ 